\title{
Impact of transgenic AFPCHI (Cucumis melo L. Silver Light) fungal resistance melon on soil microbial communities and enzyme activities
}

\author{
Ismail Bezirganoglu $\cdot$ Pinar Uysal
}

Received: 30 December 2016 / Revised: 12 February 2017 / Accepted: 14 February 2017

(c) Korean Society for Plant Biotechnology

\begin{abstract}
A greenhouse experiment was conducted for evaluation of ecological effects of transgenic melon plants in the rhizospheric soil in terms of soil properties, enzyme activities and microbial communities. Organic matter content of soil under transgenic melon plants was significantly higher than that of soil with non-transgenic melon plants. Significant variations were observed in organic matter, total $\mathrm{P}$ and $\mathrm{K}$ in soil cultivation with transgenic melon plants. There were also significant variations in the total numbers of colony forming units of fungi, actinomycetes and bacteria between soils treated with transgenic and non-transgenic melon plants. Transgenic and non-transgenic melon significantly enhanced several enzymes activities including urease, acid phosphatase, alkalin phosphatase, arysulphtase, $\beta$ glucosidase, dehydrogenase, protease and catalase. Soil polyphenoloxidase activity of $T_{1}$ transgenic melon was lower than that of $T_{0}$ transgenic melon and a non-melon plant during the same period. The first generation transgenic melon plants $\left(\mathrm{T}_{0}\right)$ showed significantly greater $(\mathrm{p}<0.05)$ effect on the activitiy of arylsulfatase, which increased from $2.540 \times 10^{6} \mathrm{CFU} \mathrm{g}^{-1}$ (control) to $19.860 \times 10^{6} \mathrm{CFU} \mathrm{g}^{-1}\left(\mathrm{~T}_{0}\right)$. These results clearly indicated that transgenic melon might change microbial communities, enzyme activities and soil chemical properties.
\end{abstract}

Keywords Chitinase, Antifugal protein, Soil enzyme, transgenic melon

Ismail Bezirganoglu $(\bowtie)$

Department of Molecular Biology and Genetics, Erzurum Technical University, 25050 Erzurum, Turkey

e-mail: ismail.bezirganoglu@erzurum.edu.tr

Pınar Uysal

Ministry of Food, Agriculture and Livestock, The Eastern Anatolia

Agricultural Research Institute, 25090, Erzurum, Turkey

\section{Introduction}

Transgenic crops have been grown commercially since 1996, and the proportion of global acreage planted with these crops has increased rapidly. Growth in the total area of transgenic crop fields increased by an unprecedented 100 fold from 1.7 million hectares in 1996 to 181.5 million hectares in 2014 (Dunfield and Germida 2004). Despite the increasing surface devoted to transgenic plants, there is growing concerns about their safety in terms of soil biota and environment (e.g. nutrient cycling), ecological effects of the newly inserted genes, and the potential risk of gene flow from transgenic plants to soil bacterial community (Brolsma et al. 2015; Powell 2007). Soil microorganisms consist of bacteria, fungi and actinomycetes. They are involved in major soil processes including mineralization, nutrient cycling, and biological nitrogen fixation, which lead to the availability of nutrients for crop production via a range of activities. Transgenic plants cultivated in soil will inevitably interact with soil microbial communities including bacteria, fungi and actinomycetes (Brolsma et al. 2015; Hartmann et al. 2008). Thus, transgenic plant products in the soil may alter ecological, physical and chemical environments like soil microbial population structure and quantity. Plant and soil associated microbial diversity are affected by not only plant species and newly introduced gene but also by environmental factors such as field area and sampling date (Donegan et al. 1996; Wang et al. 2013; Souza et al. 2013). Little studies have been reported examining potential effects of transgenes on ecosystem in soil, the mineralization of crop residues, immobilization of nutrients and soil communities. Many field studies have displayed that the impacts on soil structure and microbial communities are transient and minor when compared to the factors caused by ecological and agronomic effects (Wang et al. 2013; Wei Xiang et al. 2006). Sources of soil enzymes including living and dead microbe, plant roots and soil animal residues 
play important functions in nutrient turnover and soil quality. These enzymes play key roles in soil biochemical functions and directly influence soil productivity. Soil enzyme activities are related to soil physicochemical functions diverse microbial communities (Dick et al. 1997; Sinsabaugh et al. 1991). Glucosidase enzymes only facilitate the breakdown of organic matter. Urease is related to nitrogen cycling in the soil. On the other hand, phosphatases are associated with $\mathrm{P}$ cycles in plant growth. Dehydrogenase is related to the redox ability of the soil and widely used as a marker of biochemical process. Catalase release peroxide and its activity on organic matter content and microbe population alters in the presence of $\mathrm{CO}_{2}$ and depends on dehydrogenase activity in soil. Proteases in soil play an important role in nitrogen cycling and are greatly active in soil with excess moisture and humus contining forest soils and landfills. Arylsulphatases influence the hydrolysis of sulphate esters in soil and are secreted by microorganisms to the external environment against sulphur limitation (G. Shukla and A. Varma et al. 2012). Previous reports displayed that transgenic crops could influence enzyme activities in rhizosphere soil (Wang et al. 2013). Therefore, it is necessary to explore the effects of transgenic plants on rhizosphere soil enzyme activity when carrying out environmental safety risk assessments.

The first plants transformed by recombinant DNA technology were developed by virus resistance expressing the coat protein of the tobacco mosaic virus (TMV). The same strategy was subsequently used to produce a number of crop species to achieve novel and desired traits. These genes are inserted into the plant genome that will be decomposed finally into the soil microflora. Soil microbial communities have several opportunities to interact with novel plant gene products (Dunfield and Germida 2014). Chitinases are capable of degrading fungal cell walls and are therefore thought to play a major role in the plant's response (Collinge et al. 1993). Antifungal proteins (AFPs) belong to a group of plant defense proteins, present in different plant tissues ranging from leaves, stems, and roots to seeds (Bezirganoglu et al. 2013). The production of transgenic plants' overexpression of antifungal proteins (AFP) and chitinase gene (CHI) may confer protection to pathogen attack, and this protection is increased due to the synergic effect of the expression of two or more genes (Fiocchetti et al. 2008). Overexpression of genes encoding antifungal proteins in transgenic plants has been suggested as a method to develop resistance in response to fungal pathogens. Chitinase genes, alone or together with antifungal proteins have been introduced to some plant species and translated into novel protein of transgenic crops. In most cases, the resulting transgenic plants exhibit improved degree of fungal disease tolerance or delayed disease improvement as compared with the control plants, but environmental risk issues such as gene flow, synergism and effects on non-target organisms have been raised due to gradual production of transgenic plants with fungal disease tolerance (Nookaraju and Agrawal 2012).

Fungal diseases are among the most important factors resulting in the yield losses and caused significant yield decrease in melon. Development of disease resistance by transfer of resistance genes into crops is valuable in terms of cost and time saving. In recent years, traditional melon breeding in combination with transgenic technology has been applied to address melon fungal disease, which lead to production of some disease tolerant melon plants (Bezirganoglu et al. 2013). Using Agrobacterium tumefaciens method, AFPCHI gene was transferred to the Cucumis melo L. Silver light and a disease resistant transgenic melon line named D1 was developed. D1 line indicated stable and effective tolerance to Rhizoctonia solani and Fusarium oxysporum in a previous study (Bezirganoglu et al. 2014).

Considering the above risks, transgenic melon might change the microorganism population in rhizosphere soil and affect the soil structure and quality. Introduction of novel genes could also cause alterations in the biochemical pathways of transgenic plants and change the composition of plant root residues resulting in changes in soil enzyme activity (Wu et al. 2014). This study was done to perform the affects of transgenic melon on culturable soil microbial community diversity and enzyme activities under the greenhouse conditions.

\section{Material and Methods}

Soil material

Soil samples were obtained from $30 \mathrm{~cm}$ soil surface of a wheat field at the East Anatolia Research Institute campus Erzurum, Turkey, where no transgenic plants had ever been cultivated. The soil was air-dried and sieved $(2 \mathrm{~mm})$, soil macrofauna and gravels were mixed by a rotary drum before potting. The properties of the experimental soil were found to have $48.7 \%$ sand, $22.2 \%$ silt and $29.1 \%$ clay with a $\mathrm{pH}$ of 7.61 .

Plant material and growth conditions

Transgenic seeds of the $\mathrm{T}_{1}$ generation of AFPCHI-transgenic and $\mathrm{T}_{0}$ transgenic melon were obtained in 2016. The non- 


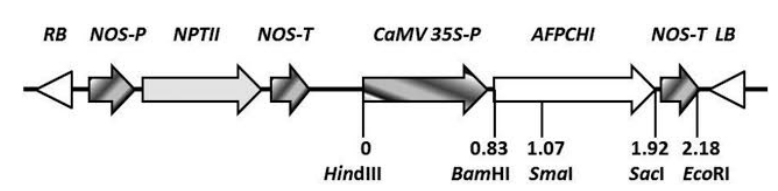

Fig. 1 Partial map of the plasmid used for melon transformation. The target gene, $A F P$ and $C H I$, were restricted into pBI121 and drived by $35 \mathrm{~S}$ promoter. $R B$, right border; Nos, promoter of Nos gene; npt II, neomycin phosphotransferase II; Nos, terminator of Nos gene; $35 \mathrm{~S}$, cauliflower mosaic virus $35 \mathrm{~S}$ promoter; $A F P$, papaya antifungal protein gene; $C H I$, papaya chitinase gene; $L B$, left border. Numbers indicate relative positions of restriction enzymes sites.

transgenic melon Cucumis melo L. Silver light, a parental plant of $A F P C H I$ was used as control (Fig. 1).

Five seeds were separately germinated in plastic pots ( $27 \mathrm{~cm}$ in diameter and $22 \mathrm{~cm}$ in height). Each pot was filled with $2 \mathrm{~kg}$ of soil and the level of nitrogen application was $300 \mathrm{mg} / \mathrm{kg}$, with an N:P:K fertilizer ratio of 1:1:2. Each type of plant had three replications and each pot was planted with one seedling; two pots without plants were included as the negative control. All pots were individually watered every four day to field capacity. The total duration for the experiment was 3 months.

\section{Soil sampling}

Rhizosphere and non rhizosphere soil samples were collected before and after sowing at the end of the green-house experiment. Plants were removed before sampling and soil samples were obtained randomly from three separated spots in rhizospheric soil. For microbial and chemical analysis, three plant cultivars were taken; each sample consisted of five sub-samples, which were collected from the three replicated pots. Soil samples were put immediately on ice during transport to the laboratory and kept at $4^{\circ} \mathrm{C}$ prior to microbial enumeration and enzyme activity tests. Samples for chemical analysis were sieved and $(<1 \mathrm{~mm})$ and kept at $4^{\circ} \mathrm{C}$ after being-air dried under room temperature condition.

\section{Soil chemical analyses}

$\mathrm{pH}$ measurement and electrical conductivity (EC) tests were carried out at $25^{\circ} \mathrm{C}$ with $1: 2.5(\mathrm{w} / \mathrm{v})$ soil to water ratio as suspension by using of an Orion $250 \mathrm{~A} \mathrm{pH}$ meter and a conductivity meter, respectively. Total organic matter was measured by wet oxidation using of a modified method of Rowell (1994). Organic matter content was determined from organic carbon by multiplying 1.724 . Total phosphorus and potassium were measured by modified ascorbic acid molybdenum blue method and atomic absorption, respectively.

Microbial enumeration

For bacteria, fungi and actinomycetes, microbial enumeration was performed by serial dilution up to $10^{6}$ and $10^{7}$ in phosphate buffered saline (PBS) and spreading on selective media. Plates were incubated on soil extract agar (SEA) at $30^{\circ} \mathrm{C}$ for 7 days.

Plates were incubated on dextrose-peptone agar (DPA) at $25^{\circ} \mathrm{C}$ for three days to grow fungi and rose bengal-malt extract agar (RBME) was used for actinomycete culture at $28^{\circ} \mathrm{C}$ for 14 days (Cynathia, 2003). After incubation period, average colony forming units (CFU) per gram of basis oven-dried soil was counted by using an automated colony calculater (Canbolat et al. 2006; Madigon et al. 2006).

Enzyme activity assays

Tested soil enzymes were urease, catalase, arylsulfatase, dehydrogenase, polyphenol oxidase, protease, $\beta$ glucosidase and acid and alkali phosphatase.

Arylsulphatase: Modified methodology of Tabatabai and Bremner (1970) was used for determination of arylsul- phatase activity. Methodology: a p-nitrophenylsulphate [4-nitrophenyl sulfate potassium salt (Sigma)] solution was added to soil $(1 \mathrm{~g})$ and incubated at $37^{\circ} \mathrm{C}$ for $1 \mathrm{~h}$. P-nitrophenol (pNP) released as a result of arylsulphatase activity was extracted and colored with $\mathrm{NaOH}$ and then measured photometrically. Urease enzyme (UE) activity: was assayed by using urea solution with an incubation time of $2 \mathrm{~h}$ and expressed as $\mu \mathrm{g}$ of NH4-N per g soil.

Dehydrogenase (DH) activity: was assayed using triphenyl tetrazolium chloride (TTC) with an incubation time of $24 \mathrm{~h}$ and expressed as $\mu \mathrm{g}$ of triphenyl formazone (TPF) per gram of soil (Tabatabati, 1994).

Soil phosphatase activity: was determined by using paranitro-phenyl phosphate (pNPP) as an orthophosphate monoester analogue substrate (Tabatabai, 1982). Briefly, we put $1 \mathrm{~g}$ of each soil sample $(<2 \mathrm{~mm})$ in a $50 \mathrm{ml}$ Erlenmeyer flask, added $4 \mathrm{ml}$ of THAM solution (Tris-hydroxymethyl-aminomethane, with citric, maleic and boric acids), buffer $(\mathrm{pH}$ 6.5 for acid phosphatase assay or $\mathrm{pH} 11$ for alkaline phosphatase assay) and $1 \mathrm{ml}$ of p-nitrophenyl phosphate solution, and swirled the flask for a few seconds to mix the contents. After stoppering the flask, we placed it in an incubator at $37^{\circ} \mathrm{C}$. After $1 \mathrm{~h}$ of incubation, we removed the stopper, added $1 \mathrm{ml}$ of $0.5 \mathrm{M} \mathrm{CaCl}_{2}$ and $4 \mathrm{ml}$ of $0.5 \mathrm{M} \mathrm{NaOH}$, and swirled the flask for a few seconds to stop the reaction. 
Then, we filtered $(0.45 \mu \mathrm{m}$ HA nitrocellulose, Milipore) the soil suspension in order to prevent the interference of possible precipitates. The fading of the intensity of yellow colour in the calibration standards, samples and controls were measured with a UV/VIS spectrophotometry (Thermo Electron Spectroscopy LTD, Cambridge, UK) at $398 \mathrm{~nm}$ against the reagent blank. We calculated the $p$-nitrophenol content by referring to a calibration curve obtained with standards containing $0,10,20,30,40$ and $50 \mathrm{ppm}$ of p-nitrophenol.

Polyphenoloxidase activity: PPO activity assays were performed in a standard reaction system using 3.4-mL Mcllvaine buffer ( $\mathrm{pH}$ 6.5), 0.4-mL 3\% catechol in the water solution and $0.2 \mathrm{~mL}$ of the PPO enzyme (E2 or E3). Increase in absorbance at $420 \mathrm{~nm}$ was automatically recorded for $3 \mathrm{~min}$ at $30^{\circ} \mathrm{C}$ using a UV-Vis spectrophotometer. One unit of enzyme activity was defined as a change of 0.001 in the absorbance value under the conditions of the assay, and PPO activity was expressed as unit per minute initial rate (Lu et al. 2006).

Catalase activity: was assessed by being based on the rates of recovery hydrogen peroxide with the residual determined by titration with $0.02 \mathrm{~mol} / \mathrm{L}$ potassium permanganate in the presence of sulphuric acid (Johnson and Temple, 1964).

Protease activity: was assessed with the method as reported by Ladd and Buttler (1972) using gelatin. Modified methodology of Tabatabai and Bremner (1970) was used for determination of arylsulphatase activity. $\beta$ glucosidase activitiy was estimated according to Eivazi and Tabatabati (1988). The enzyme actvitiy is based on spectrophotometrical measure of p-nitrophenyl released after 1 hour of incubation of soil samples at $37^{\circ} \mathrm{C}$ with pNPG in modified universal buffer (pH: 6.0) as the substrate.

Statistical Analysis: Analysis of variance and the waller Duncan $\mathrm{K}$ ratio t-test were used to determine significant differences. SPSS was used for all computations.

\section{Results}

\section{Soil Biochemical Analysis}

We observed the effects of melon plants on rhizospheric soil, as shown in Table 1 and 2. Stronger effects were found in greenhouse experiments when transgenic melon were used instead of non transgenic melon plants. After three months, a slight improvement was observed between $T_{0}$ and $T_{1}$ transgenic melon plants in terms of phosphorus when compared with non transgenic melon plants. As the rhizospheric soil potassium amount decreased, it exhibited the same amount in all the plants tested. Compared to the initial soil $\mathrm{pH}$ (7.61) and salt, the rhizospheric soil pH and salt were slightly increased by the growth of non transgenic melon. Treatment of $T_{0}$ and $T_{1}$ transgenic melon plants exhibited same trend as well. Slight alterations in the soil $\mathrm{pH}$ and salt at the end of the experiment, might probably be due to the variations in the soil nutrient status and soil buffer capacity that were induced through the addition of fertilizers. Significant increase between before sowing and after harvesting were found for both transgenic melon and non transgenic melon plants in terms of organic matter. There was considerable differences between before sowing and after harvesting in all the tested plants in terms of EC and lime.

Population of bacteria, actinomycetes and fungi

Number of bacteria, actinomycetes and fungi in rhizospheric soil were significantly different among $\mathrm{T}_{0}, \mathrm{~T}_{1}$ transgenic melon and non-transgenic melon groups. In soil, where melons were grown, numbers of culturable total microorganisms ranged from $71219.04 \times 10^{6} \mathrm{CFU} \mathrm{g}^{-1}, 44927.60 \times 10^{6} \mathrm{CFU} \mathrm{g}^{-1}$ to $25973 \times 10^{6} \mathrm{CFU} \mathrm{g}^{-1}$. In soil where non transgenic melons were grown, numbers of culturable bacteria contained lower

Table 1 Properties of the initial soil

\begin{tabular}{ccccccccc}
\hline Soil & $\begin{array}{c}\text { Saturation } \\
\%\end{array}$ & $\mathrm{pH}$ & $\begin{array}{c}\mathrm{EC} \\
\mathrm{ds} / \mathrm{m}\end{array}$ & $\begin{array}{c}\text { Salt } \\
\%\end{array}$ & $\begin{array}{c}\text { Lime } \\
\%\end{array}$ & $\begin{array}{c}\text { Organic } \\
\text { matter }(\%)\end{array}$ & $\begin{array}{c}\text { Total P } \\
\mathrm{kg} / \mathrm{da}\end{array}$ & $\begin{array}{c}\text { Total K } \\
\mathrm{kg} / \mathrm{da}\end{array}$ \\
\hline
\end{tabular}

Table 2 Properties of the experimental soil

\begin{tabular}{ccccccccc}
\hline Soil & Saturation & $\mathrm{pH}$ & $\begin{array}{c}\mathrm{EC} \\
\mathrm{ds} / \mathrm{m}\end{array}$ & $\begin{array}{c}\text { Salt } \\
\%\end{array}$ & $\begin{array}{c}\text { Lime } \\
\%\end{array}$ & $\begin{array}{c}\text { Organic } \\
\text { matter. }(\%)\end{array}$ & $\begin{array}{c}\text { Total P } \\
\mathrm{kg} / \mathrm{da}\end{array}$ & $\begin{array}{c}\text { Total K } \\
\mathrm{kg} / \mathrm{da}\end{array}$ \\
\hline $\mathrm{T}_{1}$ & 54.0 & 7.78 & 1.83 & 0.06 & 1.61 & 0.83 & 5.41 & 47 \\
$\mathrm{~T}_{0}$ & 54.0 & 7.79 & 2.03 & 0.07 & 1.29 & 0.55 & 6.00 & 47 \\
Control & 58.0 & 7.64 & 7.64 & 0.07 & 1.29 & 0.55 & 6.00 & 47 \\
\hline
\end{tabular}


Table 3 The proportion of microbial population in greenhouse soils grown with transgenic melon and non transgenic melon

\begin{tabular}{ccccc}
\hline \multirow{2}{*}{ Microbial Populations } & \multicolumn{3}{c}{ Hormones* } & \multirow{2}{*}{ Mean \pm SD } \\
\cline { 2 - 5 } & Control & $\mathrm{T}_{1}$ & $3746.60 \mathrm{a}$ & 3703,47 \\
Bacteria & $2808.80 \mathrm{c}$ & $3555.00 \mathrm{~b}$ & $238,2 \mathrm{c}$ & 425,47 \\
Actinomycetes & $416.00 \mathrm{~b}$ & $622,2 \mathrm{a}$ & $8.80 \mathrm{~b}$ & 9,02 \\
Fungi & $7.34 \mathrm{c}$ & $10.92 \mathrm{a}$ & $71219.04 \mathrm{a}$ & 47373,48 \\
Total Microbial & $25973.80 \mathrm{c}$ & $44927.60 \mathrm{~b}$ & \\
\hline
\end{tabular}

*: The differences between the means shown with lower case on the same line are significant $(\mathrm{P}<0.05)$.

$*$ : Values are mean \pm STD DEV

Table 4 Soil enzyme activities in greenhouse soils grown with $T_{0}, T_{1}$ and non-transgenic melon

\begin{tabular}{cccc}
\hline Soil enzyme & $\mathrm{C}$ & $\mathrm{T}_{0}$ & $\mathrm{~T}_{1}$ \\
\hline $\begin{array}{c}\text { Acid } \\
\text { phosphatases }\end{array}$ & $0.136 \pm 0.20$ & $0.7180 \pm 0.82$ & $0.3060 \pm 0.24$ \\
Alkaline & $1.033 \pm 0.056$ & $2.199 \pm 0.053$ & $1.182 \pm 0.016$ \\
phosphatase & & & $5.140 \pm 0.70$ \\
Arylsulfatase & $2.540 \pm 0.30$ & $19.860 \pm 1.81$ & $54.80 \pm 2.38$ \\
Catalase & $31.00 \pm 2.23$ & $84.20 \pm 3.42$ & $0.965 \pm 0.79$ \\
Dehydrogenase & $0.470 \pm 0.39$ & $1.587 \pm 0.15$ & $40.20 \pm 2.28$ \\
$\beta$ glucosidase & $26.80 \pm 1.92$ & $63.60 \pm 3.20$ & $0.6640 \pm 0.54$ \\
Protease & $0.4600 \pm 0.44$ & $0.9499 \pm 0.91$ & $0.2700 \pm 0.43$ \\
Polyphenol & $0.3660 \pm 0.23$ & $0.5624 \pm 0.26$ & \\
oxidase & & & $43.08 \pm 3.48$ \\
Urease & $31.8 \pm 3.11$ & & $67.2 \pm 4.15$ \\
\hline
\end{tabular}

microbial population of $2808.8010^{6} \mathrm{CFU} \mathrm{g}^{-1}$. In amendment of soils with $T_{0}$ or $T_{1}$, number of culturable bacteria ranged from $4746.00 \times 10^{6} \mathrm{CFU} \mathrm{g}^{-1}$ to $3555.00 \times 10^{6} \mathrm{CFU} \mathrm{g}^{-1}$. As to the number of the fungi in conditions where soils were treated with different plants, we observed that the number of rhizospheric fungi in soil grown with $\mathrm{T}_{0}\left(8.80 \times 10^{6} \mathrm{CFU}\right.$ $\left.\mathrm{g}^{-1}\right)$ and $\mathrm{T}_{1}\left(10.92 \times 10^{6} \mathrm{CFU} \mathrm{g} \mathrm{g}^{-1}\right)$ was generally higher than that of grown with non transgenic melon plants $\left(7.34 \times 10^{6}\right.$ $\left.\mathrm{CFU} \mathrm{g}^{-1}\right)$. When compared with non-transgenic melon plants, the number of the culturable actinomycetes in $T_{1}$ transgenic melon plants increased but $\mathrm{T}_{0}$ transgenic melon plants decreased in the greenhouse experiment (Table 3).

\section{Soil enzyme activities}

Compared with the control, with the exception of polyphenoloxidase activity, all tested soil enzyme activities changed gradually after grown with transgenic melon plants (Table 4). Activity of polyphenoloxidase reduced in soil grown with $\mathrm{T}_{1}$ but increased in soil grown with $\mathrm{T}_{0}$.

The activities of urease, dehydrogenase, protease, catalase, $\beta$ glucosidase, acid and alkaline phosphatase increased in soil with both transgenic plants, while arylsulfatase activity was increased with a proportion of increment of 7.82 fold in soil with $\mathrm{T}_{0}$ transgenic melon plants. Compared to non transgenic melon plants, arylsulfatase activity increased 2.02 fold in soil with $T_{1}$ transgenic melon plants. Compared to non-transgenic melon plants, the first transgenic melon plants $\left(\mathrm{T}_{0}\right)$ showed profound $(\mathrm{p}<0.05)$ effects on the activities of arylsulfatase increased by $2.540 \mathrm{x}^{6} 0^{6} \mathrm{CFU} \mathrm{g} \mathrm{g}^{-1}, 5.140 \mathrm{x}$ $10^{6} \mathrm{CFU} \mathrm{g}^{-1}$ and $19.860 \times 10^{6} \mathrm{CFU} \mathrm{g}^{-1}$ times respectively. Thus, the activities of arylsulphatase, could indicate the potential effects of transgenic melon in soil (Table 4).

\section{Discussion}

Transgenic plants possess novel traits that provide beneficial characteristic including insect or fungal resistance. These novel traits inserted in transgenic plants genome might be a significant source of environmental risk. The potential of transgenes to escape from transgenic plants to soil have been realized, however, little efforts have been made about the environmental risk assessment of transgene transfer to soil during consumption of the plants by their microbial communities. The plant associated-microbial communities 
interactions may alter microbial biodiversity and impact of macrofauna functioning has initiated a limited number of studies in the field (Dunfield and Germida 2004). In this study, transgene (AFPCHI) has been shown to cause changes in different components of the soil biota and soil biochemical properties, while also reducing availability of certain major plant nutrients and organic matter. However, there were relative differences in major plant nutrients and organic matter between the soils cultivated with transgenic and non transgenic melon. Several studies have documented reductions in plant nutrients in soil grown with transgenic plants. $\mathrm{P}$ availability in soils usually affected at main interaction zone between the plant and microorganism above the root surface in the soil. Both soil and roots microorganism are influenced by biochemical and physical properties in the soil. Biological processes that enhance soil $\mathrm{P}$ availability, root residues, including organic acids, $\mathrm{H}^{+}$ions, sugars and phosphatases, facilitate the solubilization and desorption of mineral P. Changes in the composition and community of root exudates through the expression of new protein, therefore, directly affect processes, such as manipulation of metabolic process that increase the ability of the plant to decompose organic matter, or indirectly affect availability of $\mathrm{P}$ through alterations in the biochemical pathways of rhizospheric microorganisms (Sarkar et al 2008). A strong association of the available $\mathrm{P}$ with its root parameters was found in our research, showing that improved availability of $\mathrm{P}$ might not only be due to variation in root residues, but perhaps also due to rhizospheric microorganisms. Similarly, transgenic tobacco plants expressing fungal phytase gene resulted in enhanced phosphorus nutrients when cultivated in rhizospheric soils (George et al 2005). Transgenic plants $A$. thaliana expressing alfa phytase gene showed an enhanced acquisition capacity of organic phosphorus when cultivated on phytate as the only source of phosphorus (Wang et al 2009. Xiao et al 2005).

The significant variations in the total populations of fungi, bacteria and actinomycetes were observed among the soils grown with transgenic melon and non-transgenic melon for three months. After planting melon, the total CFU of fungi, actinomycetes and bacteria increased greatly, which is presumably due to changes mediated by the genetic properties of the transgenic melon. Transgenic plants have the potential to change the microbial diversity, population size, macro and micro nutrients in the soil biota owing to the decomposition of transgene into the soil via root exudates and through decay of the crop residues. Most researches pointed that transgenic plants had significant effects on soil microbial population and had transient effects. Similar results have been reported on cotton, potato, wheat, papaya with emphasis on actinomycetes, bacterial and fungal communities (Tarafdar et al 2012, Wieinert et al 2009, Rengel et al 1998, Wei et al 2006). Fungi have potential adaptability against environmental stress, while bacteria respond to changing environment more rapidly. Consequently, both the actual and relative population of bacteria changed more quickly than those of actinomycetes and fungi regarding the similarities or differences in the environmental conditions (Wang et al. 2006). Compared with the non-transgenic melon after amended with melon, significant variations was observed in the bacterial population between the soil of non-transgenic and transgenic melon plants during three months. Populations of rhizospheric bacteria of $T_{0}, T_{1}$ are higher than those of non transgenic melon plants. Changes in the bacterial population between the non transgenic melon and transgenic melon grown soil can be featured to variations in the structure and composition of root residues that might be arranged by the AFPCHI in the transgenic plant. Alterations in the bacterial population between the soils of non transgenic melon and transgenic melon may be one of the possible cause for the little fluctuations in the organic matter contents. Similar results have been reported previously by Mamilov et al. (2001) and Wei et al. (2006).

Significant differences in the actinomycetes population were observed among the melon plants. Variation among the melon plants might be due to the alterations in the soil nutrients such as soil $\mathrm{pH}$, phosphorus and available organic matter. The correlation analysis indicated a strong correlation of organic matter and phosphorus with actinomycetes population load. In terms of plant type, populations of actinomycetes of non transgenic and transgenic melon plants were more diverse compared to bacteria and fungi. Observations in the present study also contributes to the view that the degree of actinomycetes population depends on the transgenes, plant species and the other factors. Tarafdar et al reported significantly higher actinomycetes population in non- $\mathrm{Bt}$ grown soil $\left(5.25 \times 10^{6} \mathrm{CFU} \mathrm{g}^{-1}\right)$ compared to Bt grown soil $\left(4.3 \times 10^{6} \mathrm{CFU} \mathrm{g}^{-1}\right)$. No significant variations were indicated in the studies where soils were treated with transgenic cabbage, cotton and tomato (Lin et al 2010, Sohn et al 2012, Singh et al 2012). Differences in the total actinomycetes population between the non- $\mathrm{Bt}$ and $\mathrm{Bt}$ crops may be refered to the decomposition of root residues from the transgenic brinjal into the soil that might have altered the present organic carbon and in turn, could have affected the carbon cycling (Singh et al 2013). The proportion of fungi increased and there was significant variation between transgenic melon and control plants. Significant differences of fungi populations in soil between $T_{1}$ and its parents were transient. Some 
studies recommended that the structure and the property of soil community were influenced by physiological activities of plant. Therefore, plant generation could be the favourable one for microbial proliferation due to the active decomposion of root residues. The AFPCHI gene induced effects have altered populations of fungi although it is transient in relation to plant-generation impact in the transgenic plant agroecosystem. Those were in accordance with not only previous studies showing that the genetic character had significant or various impacts on microorganism populations in amended soil, but also a recent one that the tissue of AFPCHI transgene melon have apparent impact on soil microorganisms associated with residue decomposition. Donegon et al. (1996) recommended that increase in the fungal population under the $\mathrm{Bt}$ potato planted soil was due to alterations of microbial population in the root residues.

Transgenic plants obtained by the insertion of specific resistance genes encoding for particularly efficient enzymes is a possible mean for enhanced enzymatic activities (Gianfreda 2015). Polyphenol oxidase activities in soil with $\mathrm{T}_{0}$ transgenic melon differed from the other soil enzymes; Polyphenol oxidase indicated significant variations between soils grown $T_{0}$ and $T_{1}$ transgenic melon plants. This may be attributed to soil physicochemical properties, soil enzyme origin and plant type. These results indicated that the species and number of inserted genes could not always lead to a significant alteration of enzyme activities in rhizosphere soil of transgenic plants. All enzymes' activities increased at different percentage depending on genotypic variations. The highest increase were observed for arysulfatase in $\mathrm{T}_{0}$ transgenic plant induced $A F P C H I$ protein. These variations confirm the activities of enzymes as useful indexes of alterations occurring in the total microbial functioning in soil. It seems from the results of the microbial community analysis that transgenic melon plants caused changes in the cultural soil structure. Regarding to phosphatase activity, both acid and alkaline improved by induced $A F P C H I$ transgenic melon plants, with alkaline phosphatase much higher than acid one. This is strongly influenced by the P demand of the plant species and mineralization of phosphours. Moreover, they could affect its ability to acquire phosphorus depending on genotypic variation. Different results have been reported by Tarafdar and Marschner (1994).

The results of these studies suggest that quantity and quality of effects of AFPCHI melon on soil enzyme and communities were dependent on various factors related to nature of the genetic modification. Important factors might be physico-chemical properties that are able to be involved in the bioavailability of the $A F P C H I$ proteins.

\section{References}

Bezirganoglu I, Hwang SY, Fang TJ, Shaw JF (2013) Transgenic lines of melon (Cucumis melo L. var. makuwa cv. 'Silver Light') expressing antifungal protein and chitinase genes exhibit enhanced resistance to fungal pathogens. Plant Cell Tissue Organ Culture 112:227-237

Bezirganoglu I, Hwang SY, Shaw JF, Fang TJ (2014) Efficient production of transgenic melon via Agrobacterium-mediated transformation. Gen. Mol. Res 13(2):3218-3227

Brolsma KM, Vonk JA, Hoffland E, Mulder C, Goed RGM (2015) Effects of GM potato Modena on soil microbial activity and litter decomposition fall within the range of effects found for two conventional cultivars Biol Fertil Soils 51:913-922

Canbolat MY, Bilen S, Cakmakcı R, Sahin F, Aydın A (2006) Effect of plant growth-promoting bacteria and soil compaction on barley seedling growth, nutrient uptake, soil properties and rhizospheric microflora Biol. Fertil. Soils, 42(4):350-357

Collinge DB, Kragh KM, Mikkelsen JD, Nielsen KK, Rasmussen U, Vad K (1993) Plant chitinases. Plant J 3:31-40

Cynathia SA (2003) Microbiological methods. $5^{\text {th }}$ edition. Butlerworth publicaitons. London.

Dick RP (1997) Soil enzyme activities as integrative indicators of soil health. In: Pankhurst CE, Doube BM, Gupta VVSR (eds) Biological indicators of soil health. CABI, Wellingford, pp 121-156

Donegan KK, Schaller DL, Stone JK, Ganio LM, Reed G, Hamm PB, Seidler RJ (1996) Microbial populations, fungal species diversity and plant pathogen levels in field pots of potato plants expressing the Bacillus thuringiensis var. Tenebrionis endotoxin. Transgenic Research: 25-35

Dunfield KE, Germida JJ (2004) Impact of genetically modified crop on soil-and plant associated microbial communities. J Environ Qual 38:806-815

Eivazi F, Tabatabai MA. (1988) Glucosidases and galactosidases in soils. Soil Biol. Biochem. 20:601-606

Fiocchetti F, D Amore R, De Palma M, Bertini L, Caruso C, Caporale C, Testa A, Cristinzio G, Saccardo F, Tucci M(2008) Constitutive over-expression of two wheat pathogenesisrelated genes enhances resistance of tobacco plants to Phytophthora nicotianae. Plant Cell Tissue Organ Cult 92:73-84

George TS, Richardson AE, Simpson RJ. (2005) Behaviour of plant-derived extracellular phytase upon addition to soil. Soil Biol. Biochem. 37:977-988

Gianfreda L. (2015) Enzymes of importance to rhizosphere processes. J. Soil Sci. Plant Nutr. Disponible en:http://dx.doi.org/ 10.4067/ S0718- 95162015005000022

Hartmann A, Schmid M, Van Tunien D, Berg G (2008) Plant-driven selection of microbes. Plant Soil 321:235-257

Ladd JN, Buttler HA (1972) Short-term assays of soil proteolytic enzyme activities using proteins and dipeptide derivates as substrates. Soil Biol Biochem 4:19-30

Lin CH, Pan TM (2010) Assessing the effects of genetically modified CMV-resistant tomato plant on soil microbial 
communities by PCR-DGGE. Appl Environ Microb 76:33703373

Lu S, Tong Y, Long Y, Feng H (2006) Partial purification and characterization of polyphenol oxidase from fresh cut chinese water chestnut. Journal of Food Biochemistry 30:123-137

Mamillov AS, Dilly OM (2002) Soil microbial eco-physiology as affected by short-term variations in environmental conditions. Soil biology and Biochemistry 34:1283-1290

Nookaraju, A, Agrawal, DC (2012) Enhanced tolerance of transgenic grapevines expressing chitinase and $\beta-1,3-$ glucanase genes to downy mildew. Plant Cell Tiss. Org. Cult 111:15-28

Powell JR (2007) Linking soil organisms within food webs to ecosystem functioning and environmental change. Adv Agron 96:307-350

Rengel Z, Ross G, Hirsch P (1998) Plant genotype micro-nutrient status influence colonization of wheat roots by soil bacteria. J Plant Nutr (21):99-13

Rowell DL (1994) Soil Science: Methods and Applications; Longman: Harlow, UK

Sarkar A, Patra AK, Purakayastha TJ (2008) Transgenic Bt-Cotton Affects Enzyme Activity and Nutrient Availability in a Sub-Tropical Inceptisol. J. Agronomy\&Crop Science. ISSN 0931-2250

Shukla G. and A. Varma (2011) Soil Enzymology Springer, Berlin and Heidelberg

Singh AK, Singh M, Dubey SK (2013) Changes in Actinomycetes community structure under the influence of Bt transgenic brinjal crop in a tropical agroecosystem. BMC Microbiology 13:12

Singh RJ, Ahlawat IPS, Singh S (2012) Effects of transgenic Bt cotton on soil fertility and biology under field conditions in sub-tropical Inseptisol. Environ Monit Assess 185:485-495

Sinsabaugh RL, Antibus RK, Linkins AE (1991) An enzymic approach to the analysis of microbial activity during plant litter decomposition. Agric Ecosyst Environ 34:43-54

Sohn SI, Oh YJ, Ahn BO, Ryu TH, Cho HS, Park JS, Lee KJ, Oh SD, Lee JY (2012) Soil microbial community assessment for the rhizosphere soil of herbicide resistant genetically modified Chinese cabbage. Ko J Environ Agr 31:52-59

Souza R, Beneduzi A, Ambrosini A, Costa PB, Meyer J, Vargas LK, Schoenfeld R, Passaglia LMP (2013) The effect of plant growth promoting rhizobacteria on the growth of rice (Oryza
Sativa L.) cropped in southern Brazilia fields. Plant Soil. 366:585-603

Tabatabati M.A (1994) Soil Enzymes: In: Weaver RW, Angle JS and Bottomley PS, Editors, Methods of soil Analysis: Microbiological and Biochemical Properties. Part 2. SSSA Book Ser.5, SSSA, Madison, WI, pp 775-833

Tabatabai, M.A. (1982) Soil Enzymes. En: Methods of Soil Analysis. Part 2.Chemical and Microbiological Properties. (Page, A.L. Miller, E.M., Keeney, D.R. eds.) Soil Science Society of America, Inc., Madison. pp 903-947

Tabatabai M. A., Bremner J. M. (1970) Arylsulfatase activity of soils. Soil. Sci. Soc. Am. Proc. 34:225-229

Tarafdar J.C, Marschner H. (1994) Phosphatase activity in the rhizosphere and hyposphere of VA mycorrhizal wheat supplied with inorganic and organic phosphorus Soil Biol. Biochem. 26:387-395

Tarafdar JC, Rathore I, Shiva V (2012) Effect of transgenic cotton on soil biological health. Appl Biol Res 1:15-23

Wang X, Wang Y, Tian J, Lim BL, Yan X, Liao H (2009) Overexpressing AtPAP15 enhances phosphorus efficiency in soybean. Plant Physiol 151:233-240

Wang B, Shen H, Yang X, Guo T, Zhang B, Yang W (2013) Effects of chitinase-transgenic (McChit1) tobacco on the rhizospheric microflora and enzyme activities of the purple soil. Plant Soil Environment 59:241-246

Wei XD, Zou HL, Chu LM, Liao CM, Lan CY (2006) Field released transgenic papaya affects microbial communities and enzyme activities in soil. Plant Soil 285:347-358

Weinert N, Meincke R, Gottwald C, Heuer H, Gomes NCM, (2009) Rhizosphere communities of genetically modified Zeaxanthin - accumulating potato plants and their parent cultivar differ less than those of different potato cultivars. Appl Environ Microb 75:3859-3865

Wu J, Yu M, Xu J, Du J, Ji F (2014) Impact of Transgenic Wheat with wheat yellow mosaic virus Resistance on Microbial Community Diversity and Enzyme Activity in Rhizosphere Soil. PLoS ONE 9(6): e98394. doi:10.1371/journal.pone. 0098394

Xiao K, Harrison M, Wang Z-Y (2005) Transgenic expression of a novel M. truncatula phytase gene results in improved acquisition of organic phosphorus by Arabidopsis. Planta 222:27-36 